\title{
Subject Index to Volume 38 - 2011
}

\section{5-HYDROXYTRYPTAMINE RECEPTOR \\ Variations in 5-HT2A Influence Spatial Cognitive \\ Abilities and Working Memory \\ 303 (MAR) \\ ACUTE CONFUSIONAL STATE \\ Delirium: A Review \\ 673 (SEPT) \\ ACUTE HYDROCEPHAL.US \\ Neurogenic Stunned Myocardium with Ventriculo- peritoneal Shunt Malfunction $\quad 518(\mathrm{MAY})$}

\section{ACUTE NECROTIZING ENCEPHALOPATHY}

Recurrent Acute Necrotizing Encephalopathy in a

Canadian Aboriginal Child

925 (NOV)

\section{ADAMKIEWCZ}

Spinal Cord Infarction from an Unstable Aortic Plaque

145 (JAN)

\section{ADHERENCE}

Adherence to Multiple Sclerosis Disease-Modifying

$$
\text { Therapies in Ontario is Low } 429 \text { (MAY) }
$$

\section{AFRICA}

Out of Africa, for now

373 (MAR)

\section{ALDEHYDE DEHYDROGENASE 2}

Meta-Analysis of ALDH2 Gene Polymorphism and

Alzheimer's Disease in East Asians 500 (MAY)

ALPHA RHYTHM
Generalized Nonconvulsive Status Epilepticus with
Reactive Alpha Rhythm 345 (MAR)

\section{ALTERED MENTAL STATUS}

Delirium: A Review

673 (SEPT)

\section{ALZHEIMER'S DISEASE}

Meta-Analysis of ALDH2 Gene Polymorphism and

Alzheimer's Disease in East Asians 500 (MAY)

Genetic Susceptibility of Alzheimer's Disease in East

$$
\text { Asia } 394 \text { (MAY) }
$$

Variant Alzheimer Disease with Spastic Paraparesis: A

Rare Presenilin-1 Mutation 659 (JULY)

ERK 5: A Novel IKK $\alpha$-Kinase in Rat Hippocampal

$$
\text { Neurons } 639 \text { (JULY) }
$$

Risk Profiles of Alzheimer Disease $\quad 580$ (JULY)

ARAC - The Montreal Jewish General Hospital Alzheimer Risk Assessment Clinic 600 (JULY)

Risk Assessment, Primary Prevention, and the Chronic Care Model

\section{AMYLOID}

Myopathy as the Initial Manifestation of Primary Amyloidosis

\section{AMYLOID BETA-RELATED ANGITIS}

Amyloid $\beta$-related Angiitis of the Central Nervous 626 (JULY)

Inflammation Complicates an 'Age-Related' Cerebral Microangiopathy 543 (JULY)

\section{AMYLOIDOSIS}

Myopathy as the Initial Manifestation of Primary Amyloidosis

161 (JAN)

\section{AMYOTROPHIC LATERAL SCLEROSIS}

Frontal Assessment Battery to Evaluate Frontal Lobe Dysfunction in ALS Patients 242 (MAR)

\section{ANALGESIA}

A Critical Appraisal of Sedation, Analgesia and Delirium in Neurocritical Care $\quad 815$ (NOV)

\section{ANATOMIC VARIANT}

Persistent Anterior Falcine Sinus: Demonstration by CT Angiography

$760($ SEPT)

\section{ANEURYSM}

IV Thrombolysis in Stroke From a Cavernous Carotid Aneurysm to Artery Embolus 352 (MAR)

E-Selectin Expression Increased in Human Ruptured

Cerebral Aneurysm Tissues $\quad 858$ (NOV)

\section{ANGIOLIPOMA}

A Case of Mistaken Identity: Spinal Epidural Angiolipoma

357 (MAR)

\section{ANGIOPLASTY}

Angioplasty as an Adjuvant Therapy for the Treatment of Acute Ischemic Stroke

593 (JULY)

\section{ANOSOGNOSIA}

Impact of the Cognitive Status on the Memory Complaints in MS Patients

728 (SEPT)

\section{ANTICOAGULATION}

New Anticoagulants for Atrial Fibrillation: A New Era in Stroke Prevention

777 (SEPT)

\section{ANTIVIRAL}

Early Treatment of a Progressive Rasmussen's Like Syndrome with Ganciclovir 296 (MAR)

\section{ApoE}

Normal-Pressure Hydrocephalus: Is There a Genetic Predisposition? 274 (MAR)

\section{APOLIPOPROTEIN E EPSILON 4}

Meta-Analysis of ALDH2 Gene Polymorphism and Alzheimer's Disease in East Asians 500 (MAY)

\section{APOPLEXY}

Pineal Apoplexy: Imaging Diagnosis and Follow-up of Three New Cases 931 (NOV)

\section{ARTERIOPATHY}

Reversible Wall Enhancement in Pediatric Cerebral

$$
\text { Arteriopathy }
$$

\section{ARTERIOVENOUS MALFORMATIONS}

Bipolar Electrocoagulation on Cortex after AVM

Lesionectomy for Seizure Control 48 (JAN)

Factors Predictive of Obliteration After Arteriovenous Malformation Radiosurgery 845 (NOV)

\section{ASPHYXIATION}

Asphyxiation Causing Distinctive Basal Ganglia Injury and Generalized Dystonia

514 (MAY)

\section{ASPIRIN}

Aspirin Treatment Increases the Risk of Cerebral

Microbleeds

863 (NOV)

\section{ATRIAL FIBRILLATION}

New Anticoagulants for Atrial Fibrillation: A New Era in Stroke Prevention 777 (SEPT)

Free Fatty Acids and Stroke From Atrial Fibrillation 803 (NOV)

\section{AUTOBIOGRAPHY}

Further Encounters at the Greatest Show on Earth Memoir V 220 (MAR)

Further Encounters at the Greatest Show on Earth Memoir VI 417 (MAY)

AUTONOMIC

Autonomic, EEG, and Behavioral Arousal Signs in a PVS Case After Zolpidem Intake 341 (MAR)

\section{AUTOPHAGY}

2-Methoxyestradiol Attenuates Autophagy Activation After Global Ischemia 631 (JULY)

AVM

Cyst Formation Following Radiosurgery for AVMs:

$$
\text { Report on } 3 \text { Cases }
$$

Gamma Knife for Cerebral Arteriovenous Malformations at a Single Centre 851 (NOV)

\section{AXIAL SKELETON}

Gouty Arthropathy of the Axial Skeleton Causing Cord Compression and Myelopathy $\quad 918$ (NOV)

\section{AXON OUTGROWTH}

Effect of Lentiviral shRNA of Nogo Receptor on Rat Cortex Neuron Axon Outgrowth 133 (JAN) 


\section{BACTERIAL. CO-INFECTION}

Cerebral Abscesses Resulting from HIN1 Influenza with Staphylococcal Co-Infection 147 (JAN)

\section{BASAL GANGLIA}

Asphyxiation Causing Distinctive Basal Ganglia Injury and Generalized Dystonia 514 (MAY)

BIAS

Decision Making, Bias, and Low Grade Glioma 193 (MAR)

\section{BIPOLAR ELECTROCOAGULATION}

Bipolar Electrocoagulation on Cortex after AVMs Lesionectomy for Seizure Control

48 (JAN)

\section{BLOOD PRESSURE}

Blood Pressure and Early Clinical Outcome Among Acute Ischemic Stroke Patients 225 (MAR) Blood Pressure and Acute Ischemic Stroke 187 (MAR)

\section{BRAIN ABSCESS}

Cerebral Abscesses Resulting from H1N1 Influenza with Staphylococcal Co-Infection 147 (JAN)

\section{BRAIN CYSTS}

Multiple Brain Cysts: An Unusual Form of Demyelinating Disease 774 (SEPT)

\section{BRAIN HYPER EXCITABILITY}

Too Much of a Good Thing? Brain Hyper Excitability and Migraine

189 (MAR)

\section{BRAIN INFARCTION}

Elevated Free Fatty Acid is Associated with Cardioembolic Stroke Subtype 874 (NOV)

\section{BRAIN ISCHEMIA}

Blood Pressure and Early Clinical Outcome Among Acute lschemic Stroke Patients 225 (MAR)

\section{BRAIN LESION}

The Thumb Rolling Test: A Novel Variant of the Forearm Rolling Test 129 (JAN)

Anatomical Variants of the Circle of Willis and Brain Lesions in Migraineurs 494 (MAY)

\section{BRAIN RESECTIONS}

Mitochondrial "Hypermetabolic" Neurons in Paediatric

$$
\text { Epileptic Foci }
$$
909 (NOV)

\section{BRAIN TUMOUR \\ Primary Intracranial Hemangiopericytoma Presenting as Hemiparkinsonism \\ 349 (MAR)}

\section{BREAST CANCER}

Paraneoplastic Encephalomyelitis, Stiff Person Syndrome and Breast Carcinoma 790 (SEPT)

\section{CAMPTOCORMIA}

Camptocormia: As the First Sign of Parkinson's Disease

370 (MAR)

\section{CAREGIVER}

An International Needs Assessment of Caregivers for Frontotemporal Dementia 753 (SEPT) Helping the FTD Patient-Caregiver Dyad 671 (SEPT)

\section{CAROTID}

Response to Letter to the Editor

379 (MAR)

\section{CAROTID ARTERY STENOSIS \\ Carotid Endarterectomy Versus Stenting: A Meta- Analysis of Randomized Trials 230 (MAR)}

\section{CAROTID ENDARTERECTOMY}

Carotid Endarterectomy Versus Stenting: A MetaAnalysis of Randomized Trials 230 (MAR)

\section{CAROTID STENOSIS}

Outcomes after Carotid Angioplasty and Stenting in Symptomatic Octogenarians $\quad 446$ (MAY)

Treatment of Carotid Stenosis in Octogenarians: Stenting or Surgery?

385 (MAY)

\section{CARPAL TUNNEL SYNDROME}

Patients' Perceptions of Carpal Tunnel and Ulnar Nerve Decompression Surgery

268 (MAR)

\section{CASEATING GRANULOMAS}

Intracranial Caseating Granulomas with No Infectious Organism Detected

$82(\mathrm{JAN})$

\section{CAUDA EQUINA}

Double Myxopapillary Ependymomas of the Filum

$$
\text { Terminale }
$$

\section{CAUDA EQUINA SYNDROME}

Is Prophylactic Lumbar Discectomy Ever Indicated? 375 (MAR)

\section{CENTRAL PATTERN GENERATORS}

Central Pattern Generators: A Bridge Between Life and Death

532 (MAY)

\section{CEREBELLAR AGENESIS}

Preservation of Language in the Ataxic Infant: A Case of Cerebellar Agenesis

$143(\mathrm{JAN})$

\section{CEREBELLUM}

Loss of Purkinje Cells is Associated with Demyelination in Multiple Sclerosis 529 (MAY)

\section{CEREBRAL AIR EMBOLISM}

Whole Brain CT Perfusion after Cerebral Air Embolism 522 (MAY)

\section{CEREBRAL AMYLOID ANGIOPATHY}

Amyloid $\beta$-Related Angiitis of the Central Nervous

\section{CEREBRAL ANEURYSM}

The Design of the Canadian UnRuptured Endovascular versus Surgery (CURES) Trial 236 (MAR)

Reflections on the TEAM Trial: Why Clinical Care and Research Should be Reconciled 198 (MAR)

\section{CEREBRAL CREATINE DEFICIENCY SYNDROME}

Treating Intellectual Disability; Look for Creatine Peaks in the Brain 669 (SEPT)

\section{CEREBRAL EMBOLISM}

Elevated Free Fatty Acid is Associated with Cardioembolic Stroke Subtype 874 (NOV)

\section{CEREBRAL ISCHEMIA}

2-Methoxyestradiol Attenuates Autophagy Activation After Global Ischemia 631 (JULY)

CEREBRAL, MICROBLEEDS

Aspirin Treatment Increases the Risk of Cerebral Microbleeds 863 (NOV)

\section{CERVICAL}

Minimally Invasive versus Open Approach for Cervical Laminoforaminotomy 262 (MAR)

\section{CERVICAL FLEXION MYELOPATHY}

Spinal Cord Injury after Prolonged Neck Flexion, is it an Underestimated Risk?

794 (SEPT)

\section{CERVICAL FUSION}

Comparison of Post-operative Lordosis with the PEEK Cage and the Cervical Plate $72(\mathrm{JAN})$

\section{CHANGE}

Stroke Rehabilitation in Ontario: An Opportunity for Health Care Transformation $810(\mathrm{NOV})$

A Vision for Stroke Rehabilitation Transformation in Ontario 806 (NOV)

\section{CHEMOTHERAPY}

Paraneoplastic Encephalomyelitis, Stiff Person Syndrome and Breast Carcinoma 790 (SEPT)

\section{CHIARI MALFORMATION}

Posterior Fossa Measurements in Patients With and Without Chiari I Malformation 452 (MAY)

\section{CHILDHOOD}

Prevalence of Childhood Epilepsy in Canada 719 (SEPT)

\section{CHILDREN}

Recurrent Acute Necrotizing Encephalopathy in a Canadian Aboriginal Child 925 (NOV) 


\section{CHRONIC CEREBROSPINAL VENOUS INSUFFICIENCY (CCSVI) \\ Complications in MS Patients after CCSVI Procedures Abroad (Calgary, AB) \\ 741 (SEPT) \\ Safety, Not Only Efficacy Still to be Proven for Controversial New MS Treatment 667 (SEPT)}

\section{CHRONIC ENCEPHALITIS}

Early Treatment of a Progressive Rasmussen's Like Syndrome with Ganciclovir 296 (MAR)

\section{CHRONIC PROGRESSIVE EXTERNAL OPHTHALMOPLEGIA}

Multisystem Disorder in Late-Onset Chronic

Progressive External Ophthalmoplegia 119 (JAN)

\section{CIHR}

Health Research Funding in Crisis $\quad 783$ (SEPT)

\section{CIRCLE OF WILLIS}

Anatomical Variants of the Circle of Willis and Brain Lesions in Migraineurs 494 (MAY)

\section{ClASSIFICATION}

Contemporary Treatment Strategy for Spinal

Metastasis: The "LMNOP" System 396 (MAY)

CIINIC

ARAC - The Montreal Jewish General Hospital Alzheimer Risk Assessment Clinic 600 (JULY)

\section{Clinical CARE}

Reflections on the TEAM Trial: Why Clinical Care and Research Should be Reconciled 198 (MAR)

\section{CLINICAL TRIAL \\ The Design of the Canadian UnRuptured Endovascular versus Surgery (CURES) Trial 236 (MAR) \\ More Than "Answers We Can Use", We Need to Ask the Right Questions 785 (SEPT)}

\section{CLINICOPATHOLOGIC ASSESSMENT \\ Inflammation Complicates an 'Age-Related' Cerebral Microangiopathy $\quad 543$ (JULY)}

\section{CNS VASCULITIS}

CNS Involvement in Acute Posterior Multifocal Placoid Pigment Epitheliopathy

526 (MAY)

\section{COGNITION}

Meaningful Change in Cognition in Multiple Sclerosis: Method Matters 282 (MAR)

\section{COGNITIVE}

Risk Profiles of Alzheimer Disease $\quad 580$ (JULY)

\section{COGNITIVE FUNCTIONS}

Transient Executive Dysfunction Following STN-DBS in Parkinson's Disease $\quad 360$ (MAR)

\section{COGNITIVE IMPAIRMENT}

Risk Assessment, Primary Prevention, and the Chronic Care Model

537 (JULY)

\section{CO INTOXICATION}

Improvement of Cognitive Impairment Following Delayed CO Encephalopathy 934 (NOV)

\section{COMPLEX ANEURYSMS}

Revascularization for Complex Cerebral Aneurysms 712 (SEPT)

COMPLEX PARTIAL SEIZURES

Pseudo-pseudo Epileptic Seizures: The Challenging Borderland 392 (MAY)

\section{COMPUTED TOMOGRAPHY}

Whole Brain CT Perfusion after Cerebral Air Embolism 522 (MAY)

\section{CONSCIOUSNESS}

Consciousness and Cell Memory: A Dynamic Epigenetic Interrelationship 681 (SEPT)

\section{CONVERGENCE INSUFFICIENCY}

Response to "Stereopsis in Drug Naïve Parkinson's Disease Patients" 935 (NOV)

\section{CONVERSION RATE}

Assessment of Outcome Predictors after First Attack of Optic Neuritis 887 (NOV)

\section{CORE COOLING}

Head Pre-Cooling Improves Symptoms of HeatSensitive Multiple Sclerosis Patients 106 (JAN)

\section{CORTICOBASAL DEGENERATION}

Tauopathies: One Disease or Many? 547 (JULY)

\section{CORTICO-SPINAL TRACT}

The Thumb Rolling Test: A Novel Variant of the Forearm Rolling Test

\section{CRANIOPLASTY}

In Situ Cranioplasty for Hyperostosing Meningiomas of the Cranial Vault

59 (JAN)

\section{CRANIOTOMY}

Pain Management in Post-Craniotomy Patients: A Survey of Canadian Neurosurgeons 456 (MAY)

A Death Knell for Codeine for Acute Pain after Craniotomy?

390 (MAY)

\section{CREATINE DEFICIENCY SYNDROME}

Creatine Deficiency Syndromes: Diagnostic Pearls and Pitfalls

765 (SEPT)

\section{CREE LEUKODYSTROPHY}

Neuroimaging and Neurophysiology Studies in Carriers of Cree Leukoencephalopathy 347 (MAR)

\section{CREE LEUKOENCEPHAI OPATHY}

Neuroimaging and Neurophysiology Studies in Carriers of Cree Leukoencephalopathy $\quad 347$ (MAR)

\section{CRITICAL CARE}

Rabies in the Critical Care Unit: Diagnostic and Therapeutic Approaches 689 (SEPT)

A Critical Appraisal of Sedation, Analgesia and Delirium in Neurocritical Care 815 (NOV)

\section{CROSSED CEREBELLAR DIASCHISIS}

Serial MR Imaging of Adult-Onset Rasmussen's Encephalitis

$141(\mathrm{JAN})$

CT PERFUSION

Whole Brain CT Perfusion after Cerebral Air Embolism 522 (MAY)

\section{CURES TRIAL}

CURES and the Dilemma of Unruptured Intracranial Aneurysms 191 (MAR)

Unruptured Intracranial Aneurysms; Some Questions Answered, Many Questions Remain 785 (SEPT)

\section{CUSHING'S DISEASE}

Management of Cushing's Disease After Failed Surgery - A Review

$12(\mathrm{JAN})$

\section{CYST}

Cyst Formation Following Radiosurgery for AVM:

$$
\text { Report on } 3 \text { Cases } \quad 734 \text { (SEPT) }
$$

\section{DEATH-ASSOCIATED AUTOMATISMS}

Central Pattern Generators: A Bridge Between Life and Death 5.32 (MAY)

\section{DEATH-ASSOCIATED REFLEXES}

Central Pattern Generators: A Bridge Between Life and Death 532 (MAY)

\section{DECISION MAKING}

Decision Making, Bias, and Low Grade Glioma

193 (MAR)

\section{DECOMPRESSIVE CRANIECTOMY}

Primary or Secondary Decompressive Craniectomy Different Indication and Outcome 612 (JULY) Decompressive Craniectomy for Traumatic Brain Injury 541 (JULY)

\section{DECOMPRESSIVE HEMICRANIECTOMY}

Quality of Life Following Hemicranicctomy for Malignant MCA Territory Infarction 434 (MAY)

\section{DEEP BRAIN STIMULATION}

Transient Executive Dysfunction Following STN-DBS in Parkinson's Disease $360(\mathrm{MAR})$

\section{DELIRIUM}

Delirium: A Review

673 (SEPT) 


\section{DEMENTIA}

Does Day Length Affect Cognitive Performance in Memory Clinic Patients? 461 (MAY) Risk Profiles of Alzheimer Disease

580 (JULY)

\section{DEMYELINATION}

Corpus Callosum Atrophy in a Patient with Neuromyelitis Optica

165 (JAN)

\section{DEPOLARIZATION}

Depolarization Induces NR2A Tyrosine

Phosphorylation and Neuronal Apoptosis

880 (NOV)

\section{DIAGNOSIS}

Delayed MRI Findings in Herpes simplex Encephalitis 155 (JAN)

Common Misconceptions Regarding Neuroimaging in Epilepsy Diagnosis 532 (MAY)

\section{DISC SPACE COLLAPSE}

Lumbar Microdiscectomy: A Clinicoradiological

$$
\text { Analysis of Outcome }
$$

439 (MAY)

\section{DISEASE MODIFYING THERAPY}

The Toronto Observational Study of Natalizumab in Multiple Sclerosis

\section{DONEPEZIL}

Improvement of Cognitive Impairment Following Delayed CO Encephalopathy 934 (NOV)

\section{DUCHENNE AND BECKER MUSCULAR DYSTROPHY}

A Population-Based Study of Dystrophin Mutations in Canada 465 (MAY)

\section{DUCHENNE MUSCULAR DYSTROPHY}

The Valve of Collaboration in Improving Knowledge on Rare Diseases 387 (MAY)

\section{DURAL ARTERIOVENOUS MALFORMATION}

Superficial Siderosis as a Manifestation of a Dural Arteriovenous Fistula

367 (MAR)

\section{DYSKINESIA}

OFF-Rebound Dyskinesia in Subthalamic Nucleus Stimulation in Parkinson Disease 768 (SEPT)

\section{DYSTONIA}

Peripheral Trauma Induced Dystonia or Post-Traumatic Syndrome? 22 (JAN)

Asphyxiation Causing Distinctive Basal Ganglia Injury and Generalized Dystonia 514 (MAY)

Causes for Treatment Delays in Dystonia and Hemifacial Spasm: A Canadian Survey704 (SEPT) Speech-Induced Cervical Dystonia 929 (NOV)

\section{DYSTROPHIN MUTATIONS}

A Population-Based Study of Dystrophin Mutations in Canada 465 (MAY)

\section{EARLY POST-TRAUMATIC SEIZURE}

A Critical Look at Phenytoin Use for Early Post-

Traumatic Seizure Prophylaxis 896 (NOV)

\section{EBSTEIN-BARR VIRUS}

Isolated Unilateral Hypoglossal Nerve Palsy 796 (SEPT)

\section{EDITORIAL}

Treatment of Patients with High-Grade Aneurysmal Subarachnoid Hemorrhage 3 (JAN)

MRI of Tibialis Anterior as "Surrogate Measure" in Myotonic Dystrophy Type $1 \quad 10$ (JAN)

On MR Imaging of the Intracranial Vessel Wall 4 (JAN)

Treating the Neurosurgical Patient: Beyond the Pathology and Technology I (JAN)

Ultraviolet Radiation (UVR) and Risk of Developing Multiple Sclerosis (MS) 6 (JAN)

Cause $=$ Time $\quad 8(\mathrm{JAN})$

Decision Making, Bias, and Low Grade Glioma

193 (MAR)

Blood Pressure and Acute Ischemic Stroke 187 (MAR)

Too Much of a Good Thing? Brain Hyper Excitability and Migraine 189 (MAR)

Histories of our Professions 197 (MAR)

CURES and the Dilemma of Unruptured Intracranial

$$
\text { Aneurysms } 191 \text { (MAR) }
$$

Not Just Numbers: Qualitative Research and the Clinical Neurosciences 195 (MAR)

A Death Knell for Codeine for Acute Pain after Craniotomy? 390 (MAY)

Genetic Susceptibility of Alzheimer's Disease in East Asia 394 (MAY)

The Valve of Collaboration in Improving Knowledge on Rare Diseases 387 (MAY)

Conclusions of the Available Meta-Analyses Exploring the Efficacy of Levetiracetam 388 (MAY)

Treatment of Carotid Stenosis in Octogenarians: Stenting or Surgery?

385 (MAY)

On the Urgent Need for Successful Randomized Controlled Trials in Neurosciences 383 (MAY)

Pseudo-pseudo Epileptic Seizures: The Challenging Borderland 392 (MAY)

Risk Assessment, Primary Prevention, and the Chronic Care Model 537 (JULY)

Clinical Neurology Training of Foreign Nationals in Canada - The Current Situation 539 (JULY) Inflammation Complicates an 'Age-Related' Cerebral Microangiopathy 543 (JULY)

Monoclonal Antibody Therapy and Progressive Multifocal Leukoencephalopathy 545 (JULY) Decompressive Craniectomy for Traumatic Brain Injury 541 (JULY)

Treating Intellectual Disability; Look for Creatine Peaks in the Brain $\quad 669$ (SEPT)
Helping the FTD Patient-Caregiver Dyad 671 (SEPT)

Safety, Not Only Efficacy Still to be Proven for

Controversial New MS Treatment 667 (SEPT)

Canadian Experience with Vagus Nerve Stimulation for Epilepsy in Aduits 804 (NOV)

Free Fatty Acids and Stroke From Atrial Fibrillation 803 (NOV)

Some Ramifications of Good and Evil Medicine in

$$
\text { Nazi Germany and Beyond } \quad 808 \text { (NOV) }
$$

A Vision for Stroke Rehabilitation Transformation in Ontario 806 (NOV)

\section{EDUCATION}

Web-Based Software to Assist in the Localization of

Neuroanatomical Lesions

251 (MAR)

\section{EEG}

Generalized Nonconvulsive Status Epilepticus with Reactive Alpha Rhythm 345 (MAR)

\section{EIF2B}

Neuroimaging and Neurophysiology Studies in Carriers of Cree Leukoencephalopathy 347 (MAR)

\section{ELECTRODE}

An Unusual Inflammatory Response to Implanted Deep Brain Electrodes

$168(\mathrm{JAN})$

ELLSWORTH C. ALVORD, JR.

Ellsworth C. (Buster) Alvord, Jr. (1923-2010)

\section{ENCEPHALITIS}

Rabies in the Critical Care Unit: Diagnostic and Therapeutic Approaches 689 (SEPT)

\section{ENCEPHALOPATHY}

Metronidazole-Induced Encephalopathy: Case Report and Review of MRI Findings 512 (MAY)

A Case of Phenytoin-Induced Encephalopathy in a Mathematician with Stage IV NSCLS 792 (SEPT)

Serially Changing Metronidazole-Induced Encephalopathy

921 (NOV)

\section{ENVIRONMENTAL}

A Quantitative Analysis of Suspected Environmental Causes of MS $98(\mathrm{JAN})$

Ultraviolet Radiation (UVR) and Risk of Developing Multiple Sclerosis (MS) $6(\mathrm{JAN})$

\section{EPIDEMIOLOGY}

A Quantitative Analysis of Suspected Environmental Causes of MS

98 (JAN)

Ultraviolet Radiation (UVR) and Risk of Developing Multiple Sclerosis (MS) $6(\mathrm{JAN})$

\section{EPIGENETICS}

Consciousness and Cell Memory: A Dynamic

Epigenetic Interrelationship $\quad 681$ (SEPT) 


\section{EPILEPSIA PARTIALIS CONTINUA}

Early Treatment of a Progressive Rasmussen's Like Syndrome with Ganciclovir $\quad 296$ (MAR)

\section{EPILEPSY}

Common Misconceptions Regarding Neuroimaging in

$$
\text { Epilepsy Diagnosis }
$$
532 (MAY)

Simple Partial Seizures in a 70 -Year-Old Female 507 (MAY)

Misdiagnosis of Epileptic Seizures as Manifestations of Psychiatric Illnesses 487 (MAY)

Pseudo-pseudo Epileptic Seizures: The Challenging Borderland 392 (MAY)

Prevalence of Childhood Epilepsy in Canada 719 (SEPT)

Widespread Symmetrical Subcortical Band Heterotopia 758 (SEPT)

Vagus Nerve Stimulation for Epilepsy: The Notre Dame Hospital Experience 902 (NOV)

Mitochondrial "Hypermetabolic" Neurons in Paediatric Epileptic Foci 909 (NOV)

Canadian Experience with Vagus Nerve Stimulation for Epilepsy in Adults 804 (NOV)

ERK5

ERK5: A Novel IKK $\alpha$-Kinase in Rat Hippocampal Neurons 639 (JULY)

\section{E-SELECTIN}

E-Selectin Expression Increased in Human Ruptured Cerebral Aneurysm Tissues $\quad 858$ (NOV)

ETHANOL ABUSE

Ethanol Abuse After a Right Temporal Lobe Resection for Intractable Epilepsy 787 (SEPT)

ETHICS

A Canadian Perspective on Ethics Review and Neuroimaging: Tensions and Solutions 572 (JULY)

\section{ETHICS REVIEW}

A Canadian Perspective on Ethics Review and

Neuroimaging: Tensions and Solutions 572 (JULY)

\section{FAILED SURGERY}

Management of Cushing's Disease after Failed Surgery - A Review

$12(\mathrm{JAN})$

\section{FALCINE SINUS}

Persistent Anterior Falcine Sinus: Demonstration by CT Angiography $760($ SEPT $)$

\section{FIBRO-OSSEOUS}

Simple Partial Seizures in a 70 -Year-Old Female

$$
507 \text { (MAY) }
$$

\section{FILUM TERMINALE}

Double Myxopapillary Ependymomas of the Filum

$$
\text { Terminale }
$$

\section{FIRST AID}

Depiction of Seizure First Aid Management in Medical Television Dramas

723 (SEPT)

\section{FOREIGN}

Clinical Neurology Training of Foreign Nationals in Canada - The Current Situation 539 (JULY)

\section{FOUNDER EFFECT}

Founder Mutation for $\alpha$-sarcoglycan-LGMD2D in a Magdalen Islands Acadian Cluster 747 (SEPT)

\section{FREE FATTY ACIDS}

Free Fatty Acids and Stroke From Atrial Fibrillation 803 (NOV)

\section{FRONTAL ASSESSMENT BATTERY}

Frontal Assessment Battery to Evaluate Frontal Lobe Dysfunction in ALS Patients 242 (MAR)

\section{FRONTAL LOBE DYSFUNCTION}

Frontal Assessment Battery to Evaluate Frontal Lobe Dysfunction in ALS Patients 242 (MAR)

\section{FRONTOTEMPORAL DEMENTIA}

Neuropsychological Functioning in PLS: A Comparison with ALS 88 (JAN)

An International Needs Assessment of Caregivers for Frontotemporal Dementia 753 (SEPT)

Helping the FTD Patient-Caregiver Dyad $671(\mathrm{SEPT})$

\section{FUNCTIONAL MOBILITY}

Head Pre-Cooling Improves Symptoms of HeatSensitive Multiple Sclerosis Patients 106 (JAN)

\section{FUNDING}

Health Research Funding in Crisis $\quad 783$ (SEPT) GAMMA KNIFE

Gamma Knife for Cerebral Arteriovenous Malformations at a Single Centre 851 (NOV)

\section{GASTROINTESTINAL}

Gastrointestinal Symptoms in Parkinson Disease: Clinical Aspects and Management 557 (JULY)

\section{GBA}

Glucocerebrosidase Mutations in a French-Canadian Parkinson's Disease Cohort 772 (SEPT)

\section{GENERALIZED SEIZURES}

Neuroimaging Findings in Acute Intermittent Porphyria 656 (JULY)

\section{GENETIC DATABASF}

A Population-Based Study of Dystrophin Mutations in Canada 465 (MAY)

\section{GENETIC POLYMORPHISM}

Variations in 5-HT2A Influence Spatial Cognitive Abilities and Working Memory 303 (MAR)

\section{GENETIC PREDISPOSITION}

Normal-Pressure Hydrocephalus: Is There a Genetic Predisposition? 274 (MAR)

\section{GENETIC SUSCEPTIBILITY}

Genetic Susceptibility of Alzheimer's Disease in East Asia 394 (MAY)

\section{GHANA}

Out of Africa, for now

373 (MAR)

\section{GLIOBLASTOMA}

Glioblastoma: Patterns of Recurrence and Efficacy of Salvage Treatments 621 (JULY)

GOUT

Gouty Arthropathy of the Axial Skeleton Causing Cord Compression and Myelopathy 918 (NOV)

\section{GUANIDINOACETATE METHYLTRANSFERASE} DEFICIENCY

Creatine Deficiency Syndromes: Diagnostic Pearls and Pitfalls

765 (SEPT)

\section{HIN1 SUBTYPE}

Cerebral Abscesses Resulting from H1NI Influenza with Staphylococcal Co-Infection 147 (JAN)

\section{HALOPERIDOL, WITHDRAWAL}

Recurrence of Hyperglycemic-induced Choreaballismus after Haloperidol Withdrawal

663 (JULY)

\section{HAND MOTOR CONTROL}

The Thumb Rolling Test: A Novel Variant of the

Forearm Rolling Test

$129(\mathrm{JAN})$

\section{HEALTH SERVICES RESEARCH}

Adherence to Multiple Sclerosis Disease-Modifying

Therapies in Ontario is Low

429 (MAY)

\section{HEMANGIOBLASTOMA}

Indocyanin Green Videoangiography Study of Hemangioblastomas 41 (JAN)

\section{HEMANGIOPERICYTOMA}

Primary Intracranial Hemangiopericytoma Presenting as Hemiparkinsonism 349 (MAR)

\section{HEMIFACIAL SPASM}

Causes for Treatment Delays in Dystonia and Hemifacial Spasm: A Canadian Survey 704 (SEPT)

\section{HENRY J.M. BARNETT}

Further Encounters at the Greatest Show on Earth -

Memoir V

220 (MAR) 
Further Encounters at the Greatest Show on Earth -

Memoir VI

417 (MAY)

\section{HERPES SIMPLEX ENCEPHALITIS}

Delayed MRI Findings in Herpes simplex Encephalitis

155 (JAN)

\section{HIGH-FREQUENCY OSCILLATIONS}

Subcortical Hyperexcitability in Migraineurs: A High-

$$
\text { Frequency Oscillation Study } \quad 309 \text { (MAR) }
$$

\section{HIGH GRADE ANEURYSMAL SUBARACHNOID HEMORRHAGE}

Treatment of Patients with High-Grade Aneurysmal Subarachnoid Hemorrhage

\section{HISTORY}

A History of Neurosurgery in Canada 203 (MAR) Histories of our Professions 197 (MAR) Neurolathyrism in Vapniarka: Medical Heroism in a

$$
\text { Concentration Camp } 839 \text { (NOV) }
$$

\section{HOME CARE}

Interprofessional Stroke Rehabilitation for Stroke Survivors Using Home Care

317 (MAR)

\section{HOMOZYGOUS}

Hyperekplexia: Treatment of a Severe Phenotype and Review of the Literature 411 (MAY)

\section{HUMAN EXPERIMENTATION}

Neuroscience in Nazi Europe Part I: Eugenics, Human Experimentation, and Mass Murder 696 (SEPT)

\section{HUNTINGTON'S DISEASE}

Missing Huntington's Disease for Tardive Dyskinesia: A Preventable Error

$762($ SEPT)

\section{HYPEREKPLEXIA}

Hyperekplexia: Treatment of a Severe Phenotype and Review of the Literature

411 (MAY)

\section{HYPERGLYCEMIC-INDUCED CHOREA-} BALLISMUS

Recurrence of Hyperglycemic-induced Choreaballismus after Haloperidol Withdrawal

663 (JULY)

\section{HYPEROSTOSIS}

In Situ Cranioplasty for Hyperostosing Meningiomas of the Cranial Vault

\section{HYPERPROLACTINEMIA}

A Case Report and Review of Hyperprolactinemia that is not Prolactinoma 652 (JULY)

\section{HYPOGILOSSAL NERVE PALSY}

Inolated Unilateral Hypoglossal Nerve Palsy

\section{HYPOXIA INDUCIBLE FACTOR 1}

2-Methoxyestradiol Attenuates Autophagy Activation After Global Ischemia

631 (JULY)

IgM

The Neuropathies of Waldenström's

Macroglobulinemia (WM) and IgM-MGUS

289 (MAR)

\section{INDOCYANIN}

Indocyanin Green Videoangiography Study of

$$
\text { Hemangioblastomas }
$$

$41($ JAN)

\section{INFARCTION}

Spinal Cord Infarction from an Unstable Aortic Plaque

$145(\mathrm{JAN})$

\section{INFLAMMATION \\ An Unusual Inflammatory Response to Implanted Deep Brain Electrodes \\ 168 (JAN)}

\section{INFLUENZA A VIRUS}

Cerebral Abscesses Resulting from H1N1 Influenza with Staphylococcal Co-Infection 147 (JAN)

\section{INSULIN RESISTANCE}

ERK5: A Novel IKKa-Kinase in Rat Hippocampal

Neurons

639 (JULY)

\section{INTELLECTUAL DISABILITY}

Treating Intellectual Disability; Look for Creatine

Peaks in the Brain

669 (SEPT)

\section{INTERBODY CAGE}

Comparison of Post-Operative Lordosis with the PEEK Cage and the Cervical Plate 72 (JAN)

\section{INTERNAL CAROTID ARTERY}

Low-Energy Penetrating Nail Injury Through the Petrous Segment of the ICA

649 (JULY)

\section{INTRACRANIAL ANEURYSM}

More Than “Answers We Can Use”, We Need to Ask the Right Questions

785 (SEPT)

\section{INTRACRANIAL HYPOTENSION}

Spontaneous Intracranial Hypotension: Case Series of Rare Clinical Presentations 54 (JAN)

\section{INTRACRANIAL VESSEL WALL}

On MR Imaging of the Intracranial Vessel Wall 4 (JAN)

\section{ISCHEMIC STROKE}

Blood Pressure and Acute Ischemic Stroke 187 (MAR)

Aspirin Treatment Increases the Risk of Cerebral Microbleeds

\section{LAMINOFORAMINOTOMY \\ Minimally Invasive versus Open Approach for Cervical Laminoforaminotomy 262 (MAR)}

\section{LANGUAGE}

Preservation of Language in the Ataxic Infant: A Case of Cerebellar Agenesis 143 (JAN)

\section{LATE ONSET}

Multisystem Disorder in Late-Onset Chronic Progressive External Ophthalmoplegia $119(\mathrm{JAN})$

\section{LATHYRISM}

Neurolathyrism in Vapniarka: Medical Heroism in a Concentration Camp 839 (NOV)

\section{LEPTOMENINGEAL VEINS}

Superficial Siderosis as a Manifestation of a Dural Arteriovenous Fistula 367 (MAR)

\section{LEVETIRACETAM}

Meta-Analysis of Randomized Trials on First Line and Adjunctive Levetiracetam 475 (MAY)

Conclusions of the Available Meta-Analyses Exploring the Efficacy of Levetiracetam 388 (MAY)

LGMD

Founder Mutation for $\alpha$-sarcoglycan-LGMD2D in a Magdalen Islands Acadian Cluster 747 (SEPT)

\section{LOCALIZATION}

Web-Based Software to Assist in the Localization of Neuroanatomical Lesions

251 (MAR)

\section{LORDOSIS}

Comparison of Post-Operative Lordosis with the PEEK Cage and the Cervical Plate

\section{LOW BACK PAIN}

Lumbar Microdiscectomy: A Clinicoradiological Analysis of Outcome 439 (MAY)

\section{LOW GRADE GLIOMA}

Low Grade Glioma: A Qualitative Study of the Wait and See Approach 256 (MAR)

Decision Making, Bias, and Low Grade Glioma

193 (MAR)

\section{LUMBAR MICRODISCECTOMY}

Lumbar Microdiscectomy: A Clinicoradiological Analysis of Outcome 439 (MAY)

\section{MACULAR SPARING}

A Case of Bilateral Homonymous Hemianopsia with Macular Sparing $\quad 788$ (SEPT)

MAGNETIC RESONANCE IMAGING

MRI of Tibialis Anterior Skeletal Muscle in Myotonic Dystrophy Type $1 \quad 112$ (JAN) 
MRI of Tibialis Anterior as "Surrogate Measure" in

Myotonic Dystrophy Type I

$10(\mathrm{JAN})$

MAGNETIC RESONANCE SPECTROSCOPY

Treating Intellectual Disability; Look for Creatine

Peaks in the Brain $669($ SEPT)

\section{MALFORMATIONS OF CORTICAL} DEVELOPMENT

Neuroimaging Highlight: Widespread Symmetrical Subcortical Band Heterotopia 758 (SEPT)

\section{MANAGING ANEURYSMS}

Unruptured Intracranial Aneurysms: Some Questions Answered, Many Questions Remain 785 (SEPT)

\section{MELANOMA}

Melanoma-Associated Retinopathy Report of a Case and Review

797 (SEPT)

\section{MEMORIAM}

Ellsworth C. (Buster) Alvord, Jr. (1923-2010)

171 (JAN)

Jane Marie Ruth Gillett

$662(\mathrm{JULY})$

\section{MEMORY}

Consciousness and Cell Memory: A Dynamic

Epigenetic Interrelationship

681 (SEPT)

\section{MEMORY QUESTIONNAIRE}

Impact of the Cognitive Status on the Memory

Complaints in MS Patients

728 (SEPT)

\section{MENINGIOMA}

In Situ Cranioplasty for Hyperostosing Meningiomas of the Cranial Vault

$59($ JAN)

\section{META-ANALYSIS}

Carotid Endarterectomy Versus Stenting: A MetaAnalysis of Randomized Trials 230 (MAR)

Meta-Analysis of Randomized Trials on First Line and Adjunctive Levetiracetam $\quad 475$ (MAY)

Conclusions of the Available Meta-Analyses Exploring the Efficacy of Levetiracetam 388 (MAY)

\section{METASTASES}

Contemporary Treatment Strategy for Spinal Metastasis: The "LMNOP" System 396 (MAY)

\section{METHODS}

Meaningful Change in Cognition in Multiple Sclerosis: Method Matters

282 (MAR)

\section{METRONIDAZOLE}

Metronidazole-Induced Encephalopathy: Case Report and Review of MRI Findings $\quad 512$ (MAY)

Serially Changing Metronidazole-Induced Encephalopathy

$921(\mathrm{NOV})$

\section{MICROSURGFRY}

Revascularization for Complex Cerebral Aneurysms

712 (SEPT)

\section{MIGRAINE}

Procalcitonin Levels in Migraine Patients 124 (JAN) Too Much of a Good Thing? Brain Hyper Excitability and Migraine

189 (MAR)

Anatomical Variants of the Circle of Willis and Brain

Lesions in Migraineurs

494 (MAY)

Subcortical Hyperexcitability in Migraineurs: A HighFrequency Oscillation Study 309 (MAR)

\section{MILD COGNITIVE IMPAIRMENT}

ARAC - The Montreal Jewish General Hospital Alzheimer Risk Assessment Clinic 600 (JULY)

\section{MINIMALLY INVASIVE}

Minimally Invasive versus Open Approach for Cervical Laminoforaminotomy

262 (MAR)

\section{MITOCHONDRIA}

Mitochondrial "Hypermetabolic" Neurons in Paediatric Epileptic Foci 909 (NOV)

\section{MITOCHONDRIAL TOXICITY}

Multisystem Disorder in Late-Onset Chronic Progressive External Ophthalmoplegia 119 (JAN)

\section{MONOCLONAL ANTIBODIES}

Monoclonal Antibodies and Progressive Multifocal Leukoencephalopathy

565 (JULY)

Monoclonal Antibody Therapy and Progressive Multifocal Leukoencephalopathy 545 (JULY)

\section{MONOCLONAL GAMMOPATHY OF} UNDETERMINED SIGNIFICANCE (MGUS)

The Neuropathies of Waldenström's Macroglobulinemia (WM) and IgM-MGUS

289 (MAR)

\section{MONONUCLEOSIS}

Isolated Unilateral Hypoglossal Nerve Palsy 796 (SEPT)

\section{MORPHOLOGICAI}

Posterior Fossa Measurements in Patients With and Without Chiari I Malformation

452 (MAY)

\section{MOTOR NEURON DISEASE}

Neuropsychological Functioning in PLS: A Comparison with ALS 88 (JAN)

\section{MRI}

Delayed MRI Findings in Herpes simplex Encephalitis 155 (JAN)

Preservation of Language in the Ataxic Infant in a Case of Cerebellar Agenesis 143 (JAN)

Traumatic Spinal Cord Injury Without Initial MRI Abnormality: SCIWORA Revisited 364 (MAR)
Metronidazole-Induced Encephalopathy: Case Report and Review of MRI Findings 512 (MAY)

\section{MR IMAGING}

On MR Imaging of the Intracranial Vessel Wall 4 (JAN)

\section{MULTIPLE SCLEROSIS}

A Quantitative Analysis of Suspected Environmental

$$
\text { Causes of MS } 98 \text { (JAN) }
$$

Head Pre-Cooling Improves Symptoms of HeatSensitive Multiple Sclerosis Patients 106 (JAN) Ultraviolet Radiation (UVR) and Risk of Developing Multiple Sclerosis (MS) 6 (JAN)

Meaningful Change in Cognition in Multiple Sclerosis: Method Matters 282 (MAR)

Adherence to Multiple Sclerosis Disease-Modifying Therapies in Ontario is Low 429 (MAY)

Loss of Purkinje Cells is Associated with Demyelination in Multiple Sclerosis 529 (MAY)

The Toronto Observational Study of Natalizumab in Multiple Sclerosis 422 (MAY)

Impact of the Cognitive Status on the Memory Complaints in MS Patients $\quad 728$ (SEPT)

Complications in MS Patients after CCSVI Procedures Abroad (Calgary, AB) 741 (SEPT)

Multiple Brain Cysts: An Unusual Form of Demyelinating Disease $\quad 774$ (SEPT) Safety, Not Only Efficacy Still to be Proven for Controversial New MS Treatment 667 (SEPT)

Assessment of Outcome Predictors after First Attack of Optic Neuritis 887 (NOV)

\section{MYELOPATHY}

An Unusual Case of Myelopathy: Surfer's Myelopathy 354 (MAR)

Gouty Arthropathy of the Axial Skeleton Causing Cord Compression and Myelopathy $\quad 918$ (NOV)

\section{MYOPATHY}

Myopathy as the Initial Manifestation of Primary Amyloidosis

\section{MYOTONIC DYSTROPHY}

MRI of Tibialis Anterior Skeletal Muscle in Myotonic Dystrophy Type 1 112 (JAN)

MRI of Tibialis Anterior as "Surrogate Measure" in Myotonic Dystrophy Type 1

$10(\mathrm{JAN})$

\section{MYXOPAPILLARY EPENDYMOMA}

Double Myxopapillary Ependymomas of the Filum Terminale

$151(\mathrm{JAN})$

\section{NATALIZUMAB}

The Toronto Observational Study of Natalizumab in Multiple Sclerosis 422 (MAY)

\section{NATIONAL}

Clinical Neurology Training of Foreign Nationals in Canada - The Current Situation 539 (JULY) 
NAZI

Neuroscience in Nazi Europe Part II: Resistance against the Third Reich 826 (NOV)

Some Ramifications of Good and Evil Medicine in Nazi Germany and Beyond $\quad 808$ (NOV)

\section{NAZI MEDICINE}

Neuroscience in Nazi Europe Part I: Eugenics, Human Experimentation, and Mass Murder 696 (SEPT)

\section{NECK PAIN}

An Interesting Case of Nuchal Rigidity 516 (MAY)

\section{NEUROANATOMY}

Web-Based Software to Assist in the Localization of

Neuroanatomical Lesions

251 (MAR)

\section{NEURODEGENERATION}

Loss of Purkinje Cells is Associated with

Demyelination in Multiple Sclerosis 529 (MAY)

\section{NEUROGENIC STUNNED MYOCARDIUM}

Neurogenic Stunned Myocardium with

Ventriculoperitoneal Shunt Malfunction

518 (MAY)

NEUROIMAGING

Common Misconceptions Regarding Neuroimaging in Epilepsy Diagnosis 532 (MAY)

A Canadian Perspective on Ethics Review and

Neuroimaging: Tensions and Solutions 572 (JULY)

\section{NEUROLOGIC DEFICIENCY}

Blood Pressure and Early Clinical Outcome Among Acute Ischemic Stroke Patients 225 (MAR)

\section{NEUROMUSCULAR COMMUNITY}

The Valve of Collaboration in Improving Knowledge

on Rare Diseases

387 (MAY)

\section{NEUROMYEIITIS OPTICA}

Corpus Callosum Atrophy in a Patient with

Neuromyelitis Optica

165 (JAN)

\section{NEUROPATHOLOGIST}

Ellsworth C. (Buster) Alvord, Jr. (1923-2010)

171 (JAN)

NEUROPSYCHIATRIC SEQUELAE

Improvement of Cognitive Impairment Following Delayed CO Encephalopathy 934 (NOV)

\section{NEUROSARCOIDOSIS}

Intracranial Caseating Granulomas with No Infectious Organism Detected

$82(\mathrm{JAN})$

\section{NEUROSCIENCE}

Neuroscience in Nazi Europe Part II: Resistance against the Third Reich

826 (NOV)

\section{NEUROSCIENCE STUDIES}

On the Urgent Need for Successful Randomized Controlled Trials in Neurosciences 383 (MAY)

\section{NEUROSURGERY}

Gender, Patient Comfort and the Neurosurgical Operating Room 65 (JAN)

Treating the Neurosurgical Patient: Beyond the Pathology and Technology

1 (JAN)

A History of Neurosurgery in Canada

203 (MAR)

Histories of our Professions

197 (MAR)

\section{NIGHT BLINDNESS}

Melanoma-Associated Retinopathy: Report of a Case and Review

797 (SEPT)

\section{NMDA RECEPTOR}

Depolarization Induces NR2A Tyrosine Phosphorylation and Neuronal Apoptosis

880 (NOV)

\section{NOGO RECEPTOR}

Effect of Lentiviral shRNA of Nogo Receptor on Rat Cortex Neuron Axon Outgrowth 133 (JAN)

NONCONVULSIVE STATUS

Generalized Nonconvulsive Status Epilepticus with Reactive Alpha Rhythm 345 (MAR)

\section{NONESTERIFIED FATTY ACID}

Elevated Free Fatty Acid is Associated with Cardioembolic Stroke Subtype 874 (NOV)

\section{NORMAL PRESSURE HYDROCEPHALUS}

Normal-Pressure Hydrocephalus: Is There a Genetic Predisposition?

274 (MAR)

\section{NUREMBERG CODE}

Neuroscience in Nazi Europe Part I: Eugenics, Human Experimentation, and Mass Murder 696 (SEPT)

\section{OBLITERATION}

Factors Predictive of Obliteration After Arteriovenous Malformation Radiosurgery

845 (NOV)

\section{ONCOLOGY}

A Case of Phenytoin-Induced Encephalopathy in a Mathematician with Stage IV NSCLS 792 (SEPT)

\section{OPERATING ROOM}

Gender, Patient Comfort and the Neurosurgica Operating Room 65 (JAN)

Treating the Neurosurgical Patient: Beyond the Pathology and Technology

I (JAN)

\section{OPIOID ABUSE}

Spinal Cord Injury after Prolonged Neck Flexion, is it an Underestimated Risk?

794 (SEPT)

\section{OPTIC NEURITIS}

Assessment of Outcome Predictors after First Attack of Optic Neuritis

887 (NOV)

OUTCOMES

The ASPIRE Approach for TIA Risk Stratification

78 (JAN)

\section{PAIN MANAGEMENT}

Pain Management in Post-Craniotomy Patients: A Survey of Canadian Neurosurgeons 456 (MAY) A Death Knell for Codeine for Acute Pain after

Craniotomy?

390 (MAY)

\section{PARANEOPLASTIC SYNDROME}

Paraneoplastic Encephalomyelitis, Stiff Person Syndrome and Breast Carcinoma 790 (SËPT)

\section{PARKINSON'S DISEASE}

Camptocormia: As the First Sign of Parkinson's
Disease
370 (MAR)

Primary Intracranial Hemangiopericytoma Presenting as

Hemiparkinsonism 349 (MAR)

Transient Executive Dysfunction Following STN-DBS in Parkinson's Disease 360 (MAR)

Stereopsis in Drug Naïve Parkinson's Disease Patients 299 (MAR)

Gastrointestinal Symptoms in Parkinson Disease: Clinical Aspects and Management 557 (JULY) Glucocerebrosidase Mutations in a French-Canadian Parkinson's Disease Cohort 772 (SEPT)

OFF-Rebound Dyskinesia in Subthalamic Nucleus Stimulation in Parkinson Disease 768 (SEPT) Response to "Stereopsis in Drug Naïve Parkinson's Disease Patients" 935 (NOV)

\section{PATIENT COMFORT}

Gender, Patient Comfort and the Neurosurgical Operating Room $65(\mathrm{JAN})$

Treating the Neurosurgical Patient: Beyond the Pathology and Technology 1 (JAN)

\section{PATIENT PERCEPTIONS}

Patients' Perceptions of Carpal Tunnel and Ulnar Nerve Decompression Surgery 268 (MAR)

\section{PATTERNS OF RECURRENCE}

Glioblastoma: Patterns of Recurrence and Efficacy of Salvage Treatments

\section{PEDIATRIC}

Reversible Wall Enhancement in Pediatric Cerebral Arteriopathy

139 (JAN)

\section{PENETRATING NAIL INJURY}

Low-Energy Penetrating Nail Injury Through the Petrous Segment of the ICA 649 (JULY)

\section{PERSISTENT VEGETATIVE STATE}

Autonomic, EEG, and Behavioral Arousal Signs in a PVS Case After Zolpidem Intake 341 (MAR) 


\section{PHARMACOVIGILANCE}

Monoclonal Antibodies and Progressive Multifocal Leukoencephalopathy 565 (JULY)

\section{PHENYTOIN}

A Case of Phenytoin-Induced Encephalopathy in a Mathematician with Stage IV NSCLS 792 (SEPT)

A Critical Look at Phenytoin Use for Early PostTraumatic Seizure Prophylaxis $\quad 896$ (NOV)

\section{PINEAL GLAND}

Pineal Apoplexy: Imaging Diagnosis and Follow-up of Three New Cases

931 (NOV)

\section{PITUITARY ADENOMA}

A Case Report and Review of Hyperprolactinemia that is not Prolactinoma 652 (JULY)

\section{PLACOID EPITHELIOPATHY \\ CNS Involvement in Acute Posterior Multifocal Placoid Pigment Epitheliopathy \\ 526 (MAY)}

\section{POST-OPERATIVE ANALgESIA}

Pain Management in Post-Craniotomy Patients: A Survey of Canadian Neurosurgeons 456 (MAY)

\section{POST-TRAUMATIC DYSTONIA}

Peripheral Trauma Induced Dystonia or Post-Traumatic Syndrome?

$22($ JAN)

\section{PRES}

Neuroimaging Findings in Acute Intermittent Porphyria 656 (JULY)

\section{PRESENIIIN-1}

Variant Alzheimer Disease with Spastic Paraparesis: A Rare Presenilin-1 Mutation $\quad 659$ (JULY)

\section{PREVALENCE}

Prevalence of Childhood Epilepsy in Canada

719 (SEPT)

\section{PROCALCITONIN}

Procalcitonin Levels in Migraine Patients 124 (JAN)

\section{PROGRESSIVE MULTIFOCAL} LEUKOENCEPHALOPATHY

Monoclonal Antibodies and Progressive Multifocal Leukoencephalopathy

Monoclonal Antibody Therapy and Progressive Multifocal Leukoencephalopathy 545 (JULY)

\section{PROGRESSIVE SUPRANUCLEAR PALSY}

Tauopathies: One Disease or Many? 547 (JULY)

PROPHYLACTIC SURGERY

Is Prophylactic Lumbar Discectomy Ever Indicated? 375 (MAR)

\section{PSEUDOPROLACTINOMA}

A Case Report and Review of Hyperprolactinemia that is not Prolactinoma

652 (JULY)

\section{PSEUDOTUMOUR}

Simple Partial Seizures in a 70-Year-Old Female 507 (MAY)

\section{PSYCHIATRY}

Misdiagnosis of Epileptic Seizures as Manifestations of Psychiatric Illnesses 487 (MAY)

\section{PULMONARY ARTERIOVENOUS} MALFORMATION

A Case Report of an Isolated Pulmonary Arteriovenous Malformation Causing Stroke

$158(\mathrm{JAN})$

\section{QUALITATIVE METHODS}

Not Just Numbers: Qualitative Research and the Clinical Neurosciences

195 (MAR)

\section{QUALITATIVE RESEARCH}

Low Grade Glioma: A Qualitative Study of the Wait and See Approach 256 (MAR)

Not Just Numbers: Qualitative Research and the Clinical Neurosciences

195 (MAR)

\section{QUALITY OF LIFE}

Low Grade Glioma: A Qualitative Study of the Wait and See Approach 256 (MAR)

Quality of Life Following Hemicraniectomy for Malignant MCA Territory Infarction 434 (MAY)

\section{RABIES}

Rabies in the Critical Care Unit: Diagnostic and Therapeutic Approaches 689 (SEPT)

\section{RADIOLOGICALLY ISOLATED SYNDROME}

Multiple Brain Cysts: An Unusual Form of Demyelinating Disease 774 (SEPT)

\section{RADIOSURGERY}

Gamma Knife for Cerebral Arteriovenous Malformations at a Single Centre 851 (NOV)

\section{RANDOMIZED CONTROLLED TRIAL}

Reflections on the TEAM Trial: Why Clinical Care and Research Should be Reconciled 198 (MAR)

On the Urgent Need for Successful Randomized Controlled Trials in Neurosciences 383 (MAY)

\section{RASMUSSEN'S ENCEPHALITIS}

Serial MR Imaging of Adult-Onset Rasmussen's Encephalitis

141 (JAN)

\section{RECURRENCE}

Recurrence of Hyperglycemic-induced Choreaballismus after Haloperidol Withdrawal

\section{RECURRENT}

Recurrent Acute Necrotizing Encephalopathy in a Canadian Aboriginal Child

925 (NOV)

\section{REFLECTIONS}

Out of Africa, for now

373 (MAR)

\section{REHABILITATION}

Interprofessional Stroke Rehabilitation for Stroke

Survivors Using Home Care

317 (MAR)

Stroke Rehabilitation in Ontario: An Opportunity for Health Care Transformation $\quad 810$ (NOV)

\section{RESECTION}

Indocyanin Green Videoangiography Study of

Hemangioblastomas

$41($ JAN)

\section{RESISTANCE}

Neuroscience in Nazi Europe Part II: Resistance against the Third Reich 826 (NOV)

Some Ramifications of Good and Evil Medicine in Nazi Germany and Beyond $\quad 808$ (NOV)

\section{RETINOCOCHLEOCEREBRAL}

Susac's Syndrome

335 (MAR)

\section{RETINOPATHY}

Melanoma-Associated Retinopathy Report of a Case and Review 797 (SEPT)

\section{RETROCLIVAL EPIDURAL HEMATOMA}

Pediatric Traumatic Retroclival Epidural Hematoma 338 (MAR)

\section{RETROFLEXED ODONTOID}

Pediatric Traumatic Retroclival Epidural Hematoma

338 (MAR)

\section{REVASCULARIZATION}

Revascularization for Complex Cerebral Aneurysms 712 (SEPT)

\section{REVIEW}

Gastrointestinal Symptoms in Parkinson Disease: Clinical Aspects and Management 557 (JULY)

\section{RUPTURE OF APICAL LIGAMENT}

Pediatric Traumatic Retroclival Epidural Hematoma 338 (MAR)

\section{SCIATICA}

Is Prophylactic Lumbar Discectomy Ever Indicated? 375 (MAR)

\section{SCIWORA}

Traumatic Spinal Cord Injury Without Initial MRI Abnormality: SCIWORA Revisited 364 (MAR) 


\section{SEDATION}

A Critical Appraisal of Sedation, Analgesia and Delirium in Neurocritical Care 815 (NOV)

\section{SEIZURE}

Bipolar Electrocougulation on Cortex after AVMs

Lesionectomy for Seizurc Control 48 (JAN) Spontuneous Intracranial Hypotension: Case Series of

$$
\text { Rare Clinical Presentations } 54 \text { (JAN) }
$$

Depiction of Seizure First Aid Management in Medical Television Dramas

723 (SEPT)

SiRNA

Effect of Lentiviral shRNA of Nogo Receptor on Rat

Cortex Neuron Axon Outgrowth 133 (JAN)

\section{SMALL VESSEL DISEASE}

TGF-beta 1 Codon 10 Polymorphism is Associated with Cerebral SVD 869 (NOV)

SNP

Founder Mulation for $\alpha$-sarcoglycan-LGMD2D in a Magdalen Islands Aciadian Cluster 747 (SEPT)

\section{SOMATOSENSORY EVOKED POTENTIALS}

Subcortical Hyperexcitibility in Migraineurs: A HighFrequency Oscillation Study 309 (MAR)

\section{SPASTIC PAPRAPRESIS}

Vuriunt Alzheimer Disease with Spastic Paraparesis: A Rare Presenilin-I Mutation 659 (JULY)

\section{SPEECH-INDUCED}

Speech-Induced Cervical Dystonia $929(\mathrm{NOV})$

\section{SPINAL CORD}

Spinal Cord Inlarction from an Unstable Aortic Plaque 145 (JAN)

\section{SPINAL CORD COMPRESSION}

A Calse of Mislaken Identity: Spinal Epidural Angiolipoma

357 (MAR)

\section{SPINAL CORD INJURY}

An Unusual Case of Myelopathy: Surfer's Myelopathy 354 (MAR)

Traumatic Spinal Cord Injury Without Initial MRI Abnormality: SCIWORA Revisited 364 (MAR)

Spinal Cord Injury after Prolonged Neck Flexion, is it an Underestimated Risk?

794 (SEPT)

\section{SPINAL TUMOUR}

A Case ol' Mistaken Identity: Spinal Epidural

$$
\text { Angiolipoma }
$$

\section{SPINE}

Contemporary Treatment Strategy for Spinal Metastasis: The "LMNOP" System 396 (MAY)

\section{SPINE METASTASES}

Stereotactic Radiotherapy: An Emerging Treatment for Spinal Metastases

247 (MAR)

\section{SRC}

Depolarization Induces NR2A Tyrosine Phosphorylation and Neuronal Apoptosis

$880(\mathrm{NOV})$

\section{STARTLE}

Hyperekplexia: Treatment of a Severe Phenotype and Review of the Literature

411 (MAY)

\section{STATUS EPILEPTICUS}

Serial MR Imaging of Adult-Onset Rasmussen's

Encephalitis

\section{STENTING}

Response to Letter to the Editor

$379(\mathrm{MAR})$

\section{STEREOPSIS}

Stereopsis in Drug Naïve Parkinson's Disease Patients 299 (MAR)

Response to "Stereopsis in Drug Naïve Parkinson's Disease Patients" 935 (NOV)

\section{STEREOTACTIC RADIOSURGERY}

Cyst Formation Following Radiosurgery for AVMs: Report on 3 Cases 734 (SEPT) Factors Predictive of Obliteration After Arteriovenous Malformation Radiosurgery $\quad 845$ (NOV)

\section{STEREOTACTIC RADIOTHERAPY}

Stereotactic Radiotherapy: An Emerging Treatment for Spinal Metastases

247 (MAR)

\section{STIMULATION}

Vagus Nerve Stimulation for Epilepsy: The NotreDame Hospital Experience 902 (NOV)

\section{STROKE}

The ASPIRE Approach for TIA Risk Stratification

A Case Report of an Isolated Pulmonary Arteriovenous Malformation Causing Stroke 158 (JAN)

Reversible Wall Enhancement in Pediatric Cerebral Arteriopathy 139 (JAN)

Interprofessional Stroke Rehabilitation for Stroke Survivors Using Home Care $\quad 317$ (MAR)

IV Thrombolysis in Stroke From a Cavernous Carotid Aneurysm to Artery Embolus 352 (MAR)

Outcomes after Carotid Angioplasty and Stenting in Symptomatic Octogenarians 446 (MAY) Stroke in Young Women 404 (MAY) Treatment of Carotid Stenosis in Octogenarians: Stenting or Surgery? 385 (MAY) Angioplasty as an Adjuvant Therapy for the Treatment of Acute Ischemic Stroke 593 (JULY)
A Case of Bilateral Homonymous Hemianopsia with Macular Sparing 788 (SEPT)

New Anticoagulants for Atrial Fibrillation: A New Era in Stroke Prevention 777 (SEPT)

Stroke Rehabilitation in Ontario: An Opportunity for Health Care Transformation $\quad 810$ (NOV)

Free Fatty Acids and Stroke From Atrial Fibrillation 803 (NOV)

\section{STROKE REHABILITATION}

A Vision for Stroke Rehabilitation Transformation in Ontario 806 (NOV)

\section{SUBARACHNOID HEMORRHAGE}

Proximity to the Treating Centre and Outcome Following Subarachnoid Hemorrhage $36($ JAN) Cause $=$ Time $\quad 8(\mathrm{JAN})$

\section{SUBCORTICAL, BAND HETEROTOPIA}

Neuroimaging Highlight: Widespread Symmetrical Subcortical Band Heterotopia 758 (SEPT)

\section{SUBDURAL}

Spontaneous Intracranial Hypotension: Case Series of Rare Clinical Presentations 54 (JAN)

\section{SUBTHALAMIC NUCLEUS DEEP BRAIN STIMULATION}

OFF-Rebound Dyskinesia in Subthalamic Nucleus Stimulation in Parkinson Discase 768 (SEPT)

\section{SUPERFICIAL SIDEROSIS}

Superficial Siderosis as a Manifestation of a Dural Arteriovenous Fistula 367 (MAR)

\section{SURFER'S MYELOPATHY}

An Unusual Case of Myelopathy: Surfer's Myelopathy 354 (MAR)

\section{SURGICAL}

The Design of the Canadian UnRuptured Endovascular versus Surgery (CURES) Trial 236 (MAR)

\section{SUSAC'S SYNDROME}

Susac's Syndrome

335 (MAR)

\section{SYSTEMATIC REVIEW}

Meta-Analysis of Randomized Trials on First Line and Adjunctive Levetiracetam 475 (MAY)

\section{TARDIVE DYSKINESIA}

Missing Huntington's Disease for Tardive Dyskinesia: A Preventable Error $\quad 762$ (SEPT)

TASK-SPECIFIC

Spech-Induced Cervical Dystonia 929 (NOV)

\section{TAUOPATHIES}

Tauopathies: One Disease or Many? 547 (JULY) 


\section{TELEMEDICINE}

Does Day Length Affect Cognitive Performance in Memory Clinic Patients? $461(\mathrm{MAY})$

\section{TELEVISION}

Depiction of Seizure First Aid Management in Medical Television Dramas

\section{TEMOZOLOMIDE}

Glioblastoma: Patterns of Recurrence and Efficacy of Salvage Treatments

621 (JULY)

\section{TEMPORAL ARTERITIS}

Isolated Recurrent Monocular Vision Loss as a Presentation of Temporal Arteritis 936 (NOV)

\section{TEMPORAL EPILEPSY}

Ethanol Abuse After a Right Temporal Lobe Resection for Intractable Epilepsy

787 (SEPT)

\section{TEMPORAL LOBECTOMY}

Ethanol Abuse After a Right Temporal Lobe Resection for Intractable Epilepsy 787 (SEPT)

\section{TENDINITIS}

An Interesting Case of Nuchal Rigidity 516 (MAY)

\section{THERAPY}

Angioplasty as an Adjuvant Therapy for the Treatment of Acute Ischemic Stroke

593 (JULY)

\section{THIRD REICH}

Neurolathyrism in Vapniarka: Medical Heroism in a

$$
\text { Concentration Camp }
$$

\section{THROMBOLYSIS}

IV Thrombolysis in Stroke From a Cavernous Carotid Aneurysm to Artery Embolus 352 (MAR)

TIA

The ASPIRE Approach for TIA Risk Stratification 78 (JAN)

\section{TIMELY TREATMENT}

Cause $=$ Time

$8(\mathrm{JAN})$

\section{TONSILLAR ECTOPIA}

Posterior Fossa Measurements in Patients With and Without Chiari I Malformation $\quad 452$ (MAY)

\section{TRAINING}

Clinical Neurology Training of Foreign Nationals in Canada - The Current Situation 539 (JULY)

TRANSFORMING GROWTH FACTOR - BETA 1 TGF-beta 1 Codon 10 Polymorphism is Associated with Cerebral SVD 869 (NOV)

\section{TRANSIENT MONOCULAR VISUAL LOSS}

Isolated Recurrent Monocular Vision Loss as a

Presentation of Temporal Arteritis 936 (NOV)

\section{TRANSPORTATION OF PATIENTS}

Proximity to the Treating Centre and Outcome Following Subarachnoid Hemorrhage 36 (JAN)

Management of Cushing's Disease After Failed Surgery

\section{TRANSSPHENOIDAL SURGERY}

$12(\mathrm{JAN})$

\section{TRAUMATIC BRAIN INJURY}

Primary or Secondary Decompressive Craniectomy: Different Indication and Outcome 612 (JULY)

Decompressive Craniectomy for Traumatic Brain Injury

$$
541 \text { (JULY) }
$$

A Critical Look at Phenytoin Use for Early Post-

Traumatic Seizure Prophylaxis 896 (NOV)

\section{TREATMENT}

Treatment of Patients with High-Grade Aneurysmal Subarachnoid Hemorrhage

3 (JAN)

\section{TREATMENT DELAY}

Causes for Treatment Delays in Dystonia and Hemifacial Spasm: A Canadian Survey 704 (SEPT)

\section{TREATMENT OUTCOME}

Outcomes after Carotid Angioplasty and Stenting in Symptomatic Octogenarians $\quad 446$ (MAY)

\section{TREMOR}

An Unusual Inflammatory Response to Implanted Deep Brain Electrodes 168 (JAN)

Wilson's Disease only Presenting with Isolated Unilateral Resting Tremor 939 (NOV)

\section{TUBERCULOSIS}

Intracranial Caseating Granulomas with No Infectious Organism Detected 82 (JAN)

\section{ULNAR NERVE ENTRAPMENT}

Patients' Perceptions of Carpal Tunnel and Ulnar Nerve Decompression Surgery 268 (MAR)

\section{UNRUPTURED INTRACRANIAL ANEURYSMS}

CURES and the Dilemma of Unruptured Intracranial

$$
\text { Aneurysms }
$$

191 (MAR)

Unruptured Intracranial Aneurysms: Some Questions Answered, Many Questions Remain 785 (SEPT)

\section{VAGUS}

Vagus Nerve Stimulation for Epilepsy: The Notre-

Dame Hospital Experience

\section{VAGUS NERVE STIMULATION}

Canadian Experience with Vagus Nerve Stimulation for Epilepsy in Adults 804 (NOV)

\section{VASCULITIS}

Isolated Recurrent Monocular Vision Loss as a Presentation of Temporal Arteritis 936 (NOV)

\section{VASCULOPATHY}

Susac's Syndrome

335 (MAR)

\section{VENOUS DURAL SINUS}

Persistent Anterior Falcine Sinus: Demonstration by CT Angiography $760($ SEPT)

\section{VENTRICULOPERITONEAL SHUNT} MALFUNCTION

Neurogenic Stunned Myocardium with Ventriculoperitoneal Shunt Malfunction $518(\mathrm{MAY})$

\section{VISUAL SPATIAL COGNITIVE ABILITY}

Variations in 5-HT2A Influence Spatial Cognitive Abilities and Working Memory 303 (MAR)

\section{WALDENSTRÖM'S MACROGLOBULINEMIA}

The Neuropathies of Waldenström's

Macroglobulinemia (WM) and IgM-MGUS 289 (MAR)

\section{WILSON'S DISEASE}

Wilson's Disease only Presenting with Isolated

Unilateral Resting Tremor 939 (NOV)

WOMEN

Stroke in Young Women 404 (MAY)

YOUNG

Stroke in Young Women

404 (MAY)

\section{ZOL.PIDEM}

Autonomic, EEG, and Behavioral Arousal Signs in at PVS Case After Zolpidem Intake 341 (MAR) 